\title{
Source of variation detected in ribotyping patterns of Haemophilus influenzae: comparison of traditional ribotyping, PCR-ribotyping and rDNA restriction analysis
}

\author{
J. ZOE JORDENS* and N. I. LEAVES†
}

PHLS Haemophilus Reference Laboratory, Oxford Public Health Laboratory, John Radcliffe Hospital, Oxford OX3 9DU

\begin{abstract}
The pattern of EcoRI restriction fragments of chromosomal DNA that hybridise with a probe for genes encoding 16S and 23S rRNA is highly discriminatory for non-capsulate Haemophilus influenzae (NCHI). The source of variation detected by these probe-based ribotyping patterns was investigated by restriction analysis of rRNA operon (rrn) amplification products from nine representative strains. Digestion of $r \boldsymbol{r}$ amplification products with EcoRI indicated one conserved EcoRI site within 16S rDNA and no EcoRI sites within the $16 \mathrm{~S}-23 \mathrm{~S}$ intergenic spacer region of the nine strains, and an $E c o R I$ site at the $5^{\prime}$ end of $23 S$ rDNA from seven of the nine strains. Comparison of the EcoRI ribotyping patterns obtained with separate probes for $16 \mathrm{~S}$ and $23 \mathrm{~S}$ rDNA showed more variation with the $23 \mathrm{~S}$ probe indicating variation in EcoRI sites downstream from the operon. Restriction analyses of $16 \mathrm{~S}$ and $23 \mathrm{~S}$ rDNA amplification products with $A l u \mathrm{I}$, Hha I, Hae III and TaqI divided the nine 'traditional' ribotypes into a maximum of three and eight groups, respectively. Similar analyses of the $16 \mathrm{~S}-23 \mathrm{~S}$ intergenic regions (PCR-ribotyping) failed to distinguish any of the nine representative strains. Therefore, there is probably insufficient variation within the operon for it to form a good target for PCR-based typing methods. In contrast, 'traditional' ribotyping with cDNA from 16S plus 23S rRNA detects restriction site differences in the sequences flanking the operon, which show considerably more variation between strains. 'Traditional' ribotyping should therefore remain the standard for characterising NCHI in epidemiological investigations.
\end{abstract}

\section{Introduction}

The pattern of restriction fragments of chromosomal DNA that hybridise with probes for the operon encoding rRNA ( $\mathrm{rr}$ ) has been applied successfully to both the inter- and intra-species characterisation of a wide range of bacteria [1]. With the appropriate choice of restriction endonuclease and probe for the species under investigation, this method (ribotyping) has been shown to detect sufficient heterogeneity within many species to provide useful epidemiological information [2]. The source of the heterogeneity in ribotyping

Received 3 Dec. 1996; revised version accepted 29 Jan. 1997. Corresponding author: Dr J. Z. Jordens.

${ }^{*}$ Present address: Molecular Microbiology Level C, South Block, Southampton General Hospital, Southampton SO16 6 YD.

$\dagger$ Present address: Wellcome Trust Centre for Human Genetics, Nuffield Orthopaedic Centre, Windmill Road, Headington, Oxford OX3 7BN. patterns is unknown [1], but may be caused by variations within $r r n$, i.e., in the genes encoding $16 \mathrm{~S}$ rRNA, 23S rRNA, 5S rRNA or the two intergenic spacer regions (IGS), or in the regions flanking the multiple $r r n$ copies that are present within most strains.

Ribotyping patterns obtained from EcoRI-digested chromosomal DNA hybridised with a cDNA probe for $16 \mathrm{~S}$ and $23 \mathrm{~S}$ rRNA-encoding genes (rDNA) have been shown to be a highly discriminatory method for characterising strains of non-capsulate Haemophilus influenzae (NCHI) from nosocomial outbreaks of respiratory infection [3]. However, ribotyping involves lengthy procedures for DNA extraction, digestion, blotting, hybridisation and detection, and often takes up to 1 week to provide a result; more rapid methods are desirable for hospital infection control purposes. PCR-based methods of characterisation based on randomly amplified polymorphic DNA (RAPD) have been shown to correlate well with ribotyping for $\mathrm{NCHI}$ [3], but inter-laboratory reproducibility of 
RAPD is poor [4]. PCR-based methods of strain characterisation that specifically target $r r n$ sequences have been applied to the inter- and intra-species characterisation of bacteria. Amplified $16 \mathrm{~S}$ rDNA restriction analysis (16S ARDRA) has been shown to differentiate species of mycobacteria [5], some Acinetobacter spp. [6], streptococci [7] and Prevotella spp. [8], and has been shown to discriminate between and within some fluorescent Pseudomonas spp. [9]. Amplification of the 16S-23S IGS, which may vary in length and sequence between the multiple copies of $r r n$ that are usually present within a genome, has been shown to differentiate between genera and species [10], and also between unrelated strains within Burkholderia (Pseudomonas) cepacia [11, 12], Clostridium difficile [13] and Neisseria meningitidis [14]. This method has been referred to as PCR-ribotyping [15]. Restriction analysis of amplification products containing IGS plus a portion of 23S rDNA has been shown to differentiate strains of Rochalimeae henselae [16]. PCR-ribotyping and 16S ARDRA have been applied predominantly to inter-species characterisation, i.e., for identification rather than typing or strain characterisation purposes. The ability of these methods to detect heterogeneity within species, as required for epidemiological studies, has yet to be determined for many important pathogens, including $H$. influenzae. The relationship between the results of 'traditional' ribotyping with different probes, ARDRA and PCRribotyping has not been studied.

For species with insufficient IGS length heterogeneity, it may be possible to increase the discriminatory ability of PCR-ribotyping by restriction analysis of the products. In addition, ARDRA based on 23S rDNA-which is $60 \%$ larger than $16 \mathrm{~S}$ rDNA and is associated with a faster rate of sequence change than $16 \mathrm{~S}$ rDNA [17]may be more discriminatory than $16 \mathrm{~S}$ rDNA-based ARDRA. The present study investigated the source of variation detected in traditional ribotyping patterns to determine the suitability of $r r n$ as targets for PCR-based methods of strain characterisation. This was achieved by restriction analysis of PCR-amplified 16S rDNA, 23S rDNA and 16S-23S IGS, and by comparative hybridi- sation studies with three different probes: cDNA from $16 \mathrm{~S}$ plus 23S rRNA, and separate PCR-generated probes for $16 \mathrm{~S}$ and $23 \mathrm{~S}$ rDNA. The methods were also compared for their intra-species characterisation of $\mathrm{NCHI}$ in epidemiological investigations.

\section{Materials and methods}

\section{Isolates}

As part of a survey of antimicrobial resistance in $H$. influenzae by Bath Public Health Laboratory, $20 \beta$ lactamase-negative strains with reduced susceptibility to $\beta$-lactam agents were isolated and $20 \beta$-lactamsusceptible strains were selected from age-matched patients as controls [18]. All isolates were received in Oxford on heated blood (chocolate) agar slopes and subcultured on to chocolate agar with overnight incubation at $37^{\circ} \mathrm{C}$ in a humidified atmosphere containing $\mathrm{CO}_{2} 5 \%$. The growth was harvested and stored at $-80^{\circ} \mathrm{C}$ in Protect vials (Technical Services Consultants, Heywood, Lancs.). As part of the Bath survey, the 40 isolates had been characterised by EcoRI ribotyping with a digoxigenin-labelled cDNA probe made from purified 16S and 23S rRNA from Escherichia coli as described previously [3, 18]. These 40 isolates were further characterised by traditional ribotyping with a probe for $16 \mathrm{~S}$ rDNA, as described below, and nine of these isolates with different ribotyping patterns were selected for further analyses. Total cellular DNA was extracted as described previously [19].

\section{PCR-generated $16 S$ rDNA probe}

For the digoxigenin-labelled 16S rDNA probe, $c .1 .5 \mathrm{~kb}$ of 16S rRNA-encoding DNA (corresponding to nucleotides $8-1540$ in $E$. coli) was amplified from $H$. influenzae type b (HIB) strain Eagan [20] with primers 5'-AGAGTTTGATCATGGCTCAG-3' [21] (Fig. 1; F2) and 5'-AGGAGGTGATCCAACCGCA-3' [22] (Fig. 1; R2). Amplification was in a total volume of $25 \mu 1$ and contained $0.3 \mu \mathrm{M}$ of each primer, $250 \mu \mathrm{M}$ of each dNTP and $0.1 \mathrm{U}$ of Taq polymerase (Advanced Biotechnologies Ltd, Leatherhead, Surrey) in the

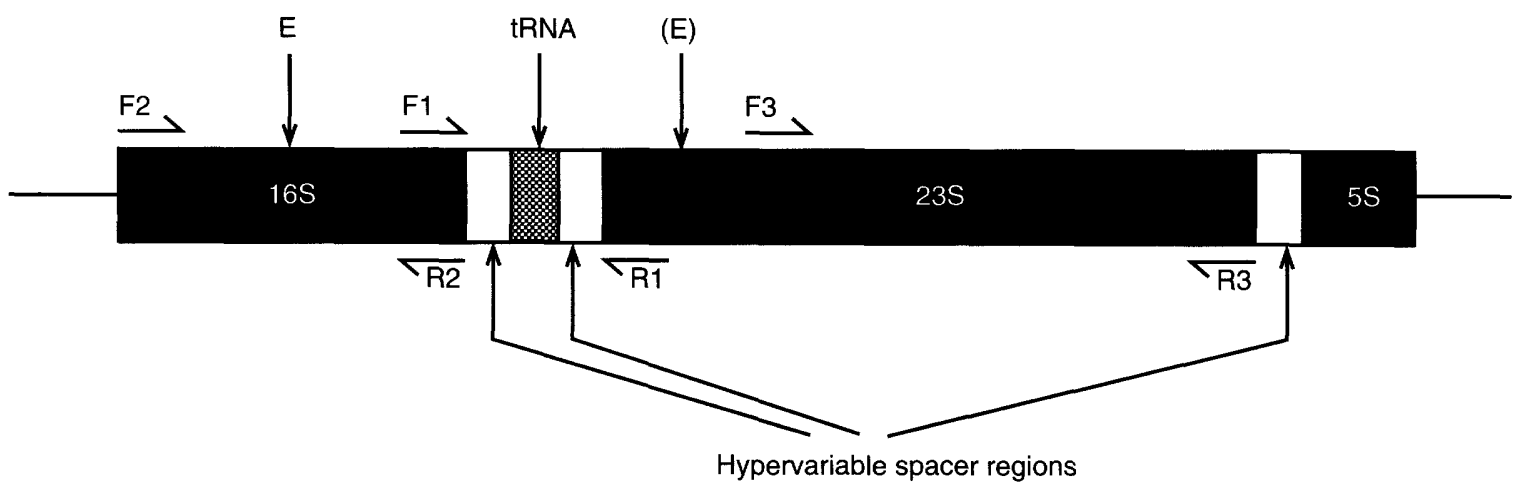

Fig. 1. Schematic representation of a $r r n$ operon showing the relative position and orientation of primers used in the present study (not to scale). E, stable EcoRI site; (E), unstable EcoRI site. 
presence of the buffer supplied with the polymerase (buffer IV, containing $1.5 \mathrm{mM} \mathrm{MgCl}_{2}$ ). This reaction mixture was overlaid with mineral oil, and $c .1 \mu \mathrm{g}$ of target DNA was added. A control tube containing all reagents except target DNA was included in all amplification experiments. Amplification conditions comprised 25 cycles of $1 \mathrm{~min}$ at $94^{\circ} \mathrm{C}, 1 \mathrm{~min}$ at $55^{\circ} \mathrm{C}$ and $2 \mathrm{~min}$ at $72^{\circ} \mathrm{C}$, followed by $10 \mathrm{~min}$ at $72^{\circ} \mathrm{C}$. Amplification products $(10 \mu 1)$ were separated by electrophoresis in agarose $0.9 \% \mathrm{w} / \mathrm{v}$ gels in TBE buffer $\left(89 \mathrm{mM}\right.$ Tris, $89 \mathrm{mM}$ boric acid, $2 \mathrm{mM} \mathrm{Na} \mathrm{Na}_{2}$ EDTA), stained with ethidium bromide $(1 \mu \mathrm{g} / \mathrm{ml})$ and photographed under ultraviolet transillumination. A portion $(1 \mu 1)$ of the initial amplification products was used as target in a second round of amplification with the same reaction conditions except that dig-11-dUTP (Boehringer Mannheim) replaced 35\% of the dTTP. The mobility of the resulting product in agarose gel electrophoresis was compared with the unlabelled product and shown to be retarded, indicating successful incorporation of digoxigenin.

\section{PCR-generated probe for $23 S$ rDNA}

A segment (c. $2.6 \mathrm{~kb}$ ) of $23 \mathrm{~S}$ rDNA (corresponding to nucleotides 188-2744 in E. coli) was amplified from HIB strain Eagan [20] with primers previously designated $11 \mathrm{a} \quad\left(5^{\prime}\right.$-GGAACTGAAACATCTAAGTA$\left.3^{\prime}\right)$ and 97ar (5'-CCCGCTTAGATGCTTTCAGC-3') [23] (Fig. 1; F3 and R3, respectively). Amplification reactions $(25 \mu \mathrm{l})$ contained $0.5 \mu \mathrm{M}$ of each primer; other reagents were as above for $16 \mathrm{~S}$ rDNA. Amplification conditions comprised 25 cycles of $1 \mathrm{~min}$ at $94^{\circ} \mathrm{C}, 1 \mathrm{~min}$ at $55^{\circ} \mathrm{C}$ and $2.5 \mathrm{~min}$ at $72^{\circ} \mathrm{C}$. The product $(1 \mu 1)$ was used as the target in the PCR labelling reaction, as described above for the $16 \mathrm{~S}$ rDNA probe.

\section{Ribotyping with PCR-generated probes for $16 \mathrm{~S}$ and $23 S$ rDNA}

Southern blots of total cellular DNA digested with EcoRI were hybridised with the PCR-generated probe for $16 \mathrm{~S}$ rDNA with the same highly stringent conditions as traditional ribotyping [3]. Nine strains showing different ribotyping patterns (when hybridised with the cDNA probe), including two pairs indistinguishable when hybridised with the $16 \mathrm{~S}$ rDNA probe, were investigated further by ribotyping with the PCR-generated probe for $23 \mathrm{~S}$ rDNA and by the techniques below.

\section{Restriction analysis of $16 S$ rDNA and $23 S$ rDNA}

A segment $(c .1 .5 \mathrm{~kb})$ of $16 \mathrm{~S}$ rDNA was amplified from each strain with the same primers and conditions used to make the $16 \mathrm{~S}$ rDNA probe, except that reagents were scaled up to give final reaction volumes of $100 \mu \mathrm{l}$. After amplification, a $5-\mu 1$ portion was electrophoresed on an agarose $2 \% \mathrm{w} / \mathrm{v}$ gel in TBE containing ethidium bromide $1 \mu \mathrm{g} / \mathrm{ml}$ to check the amount and purity of product. For restriction analysis, $8 \mu$ l of the product were digested with one of four restriction endonucleases with four-base recognition sequences ( $A l u \mathrm{I}$, Hae III, HhaI and Taq I) and EcoRI (the enzyme used for ribotyping) and the conditions recommended by the manufacturer (Life Technologies, Paisley). Digestion products were electrophoresed initially on agarose $2 \% \mathrm{w} / \mathrm{v}$ gels, followed by polyacrylamide $10 \% \mathrm{w} / \mathrm{v}$ if products of $<c .200 \mathrm{bp}$ were detected. Amplification and digestion products were occasionally stored at $-20^{\circ} \mathrm{C}$ before electrophoresis. Amplification of $23 \mathrm{~S}$ rDNA was as described above for $23 \mathrm{~S}$ probe preparation, except that the reaction volume was increased to $100 \mu \mathrm{l}$. Digestion products were separated on Metaphor ${ }^{\mathrm{TM}}$ Agarose (FMC Products, Flowgen Instruments, Sittingbourne, Kent) $2 \% \mathrm{w} / \mathrm{v}$ gels in TBE to increase the resolution of fragments of 100-1000 bp. All other conditions were as described for $16 \mathrm{~S}$ rDNA restriction analysis. All strains were analysed on at least three separate occasions.

\section{$P C R$ ribotyping}

The 16S-23S rDNA IGS was amplified with primers 5'-GAAGTCGTAACAAGG-3' and 5'-CAAGGCATCCACCGT-3' [10] (Fig. 1; F1 and $\mathrm{R} 1$, respectively). Amplifications were performed in total reaction volumes of $100 \mu \mathrm{l}$ as described previously [10]. A 5- $\mu 1$ sample of the products was electrophoresed on agarose $1.6 \% \mathrm{w} / \mathrm{v}$ gels in TBE containing ethidium bromide $(1 \mu \mathrm{g} / \mathrm{ml})$. An $8-\mu 1$ portion of these products was digested with one of five restriction endonucleases, as above.

\section{Other amplifications}

The 23S rDNA product amplified above lacked $187 \mathrm{bp}$ at the $5^{\prime}$-end and, although $c .20 \mathrm{bp}$ were included in the IGS amplification product [10], c. $170 \mathrm{bp}$ were not examined for EcoRI restriction sites. To detect EcoRI sites within this region, primers $F 1$ and F2 were each used with R3. For the larger product (F2-R3; c. $5 \mathrm{~kb}$ ), the proof-reading enzyme complex BIO-X-ACT (kindly provided by Bioline UK Ltd, London) was used. Amplification conditions comprised an initial $5 \mathrm{~min}$ at $94^{\circ} \mathrm{C}$, followed by 20 cycles of $1 \mathrm{~min}$ at $94^{\circ} \mathrm{C}$, $1 \mathrm{~min}$ at $55^{\circ} \mathrm{C}$ and either $3 \mathrm{~min}$ (for the $\mathrm{F} 1-\mathrm{R} 3$ product) or $5 \mathrm{~min}$ (for the $\mathrm{F} 2-\mathrm{R} 3$ product) at $72^{\circ} \mathrm{C}$, and a final extension period of $10 \mathrm{~min}$ at $72^{\circ} \mathrm{C}$. Products were digested with EcoRI as described above. The F2-R3 product was also digested with Hae III and the products were separated on Metaphor ${ }^{\mathrm{TM}}$ agarose $2 \% \mathrm{w} / \mathrm{v}$ gels in TBE.

\section{Results}

\section{Traditional probe-based ribotyping}

The cDNA probe for $16 \mathrm{~S}$ and $23 \mathrm{~S}$ rDNA had previously identified 24 patterns among the 39 typable isolates: 16 patterns for 19 susceptible isolates and 
eight different patterns for 20 resistant isolates [18]. The 16S PCR-generated probe used in the present study identified 22 patterns among the 39 isolates: 15 patterns for the 19 susceptible isolates and eight patterns for the resistant isolates. There was excellent correlation between the results of the two techniques but, in contrast to the cDNA probe, the $16 \mathrm{~S}$ probe did not distinguish between two ampicillin-susceptible strains or between one ampicillin-susceptible strain and an ampicillin-resistant strain. Nine representative strains with different ribotyping patterns (obtained following hybridisation with the cDNA probe for $16 \mathrm{~S}$ and $23 \mathrm{~S}$ rDNA), including the four isolates that gave indistinguishable patterns when hybridised with the probe for $16 \mathrm{~S}$ rDNA alone, were characterised by hybridisation with a probe for $23 \mathrm{~S}$ rDNA. These nine strains were all distinguishable by ribotyping with the $23 \mathrm{~S}$ rDNA probe. The ribotyping patterns of these nine strains obtained following hybridisation with $16 \mathrm{~S}$ and $23 \mathrm{~S}$ cDNA probe, the $16 \mathrm{~S}$ rDNA probe and the $23 \mathrm{~S}$ rDNA probe are shown in Figs. $2 a$ and $b$. The nine strains were further characterised by restriction analysis of $16 \mathrm{~S}$ rDNA and 23S rDNA, and amplification and restriction analysis of $16 \mathrm{~S}-23 \mathrm{~S}$ IGS.

\section{Restriction analysis of $16 S \mathrm{rDNA}$}

A $1.5-\mathrm{kb} 16 \mathrm{~S}$ rDNA product was amplified from the nine study strains and digested with five different restriction endonucleases. EcoRI digestion resulted in two bands of $c .700 \mathrm{bp}$ and $c .800 \mathrm{bp}$; there was no variation in the sizes of these two fragments between the different strains (data not shown). The enzymes with four-base recognition sequences each gave one to three different patterns (each consisting of three to seven bands in the $c$. 150-500 bp size range) for the nine strains (Fig. 3; Table 1).

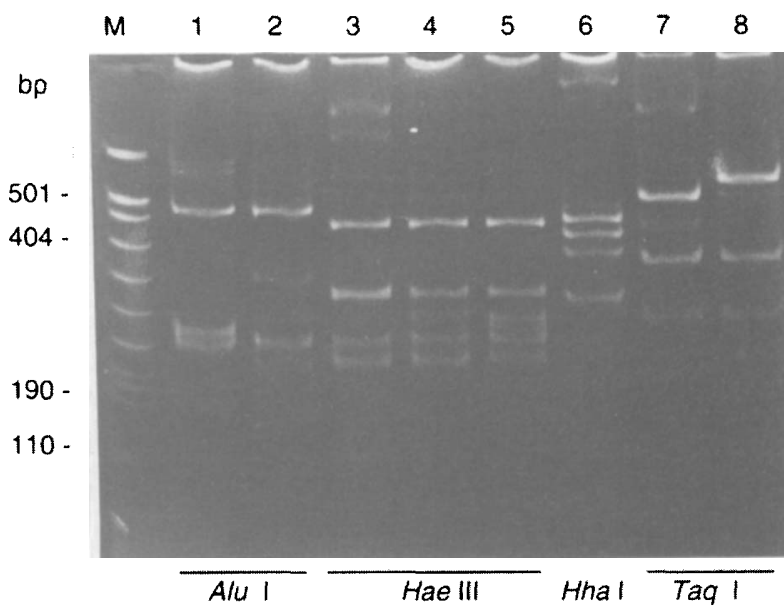

Fig. 3. Restriction analysis of $16 \mathrm{~S}$ rDNA amplification products. Digestion with $A l u \mathrm{I}$ gave two restriction patterns (A1 and A2; lanes 1 and 2, respectively). Digestion with Hae III gave three restriction patterns (E1, E2 and E3; lanes 3, 4 and 5, respectively). Digestion with Hha I gave a single restriction pattern (H1; lane 6). Digestion with Taq I gave two restriction patterns ( $\mathrm{T} 1$ and $\mathrm{T} 2$; lanes 7 and 8 , respectively). M, molecular size marker (Marker VIII, Boehringer). (a) $\quad \begin{array}{llllllllll}M & 1 & 2 & 3 & 4 & 5 & 6 & 7 & 8 & 9\end{array}$

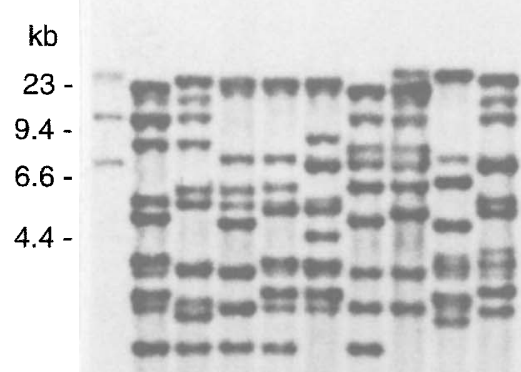

$2.3-$

$2.0-$

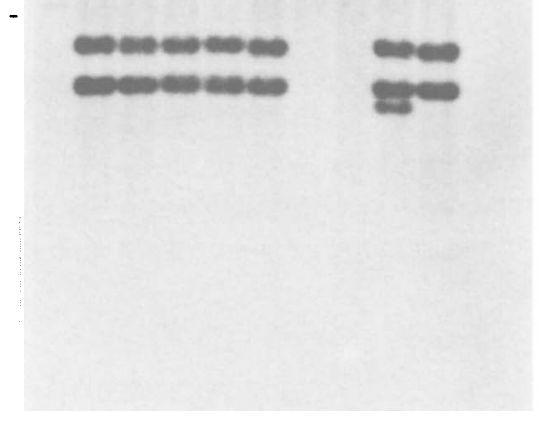

(b)
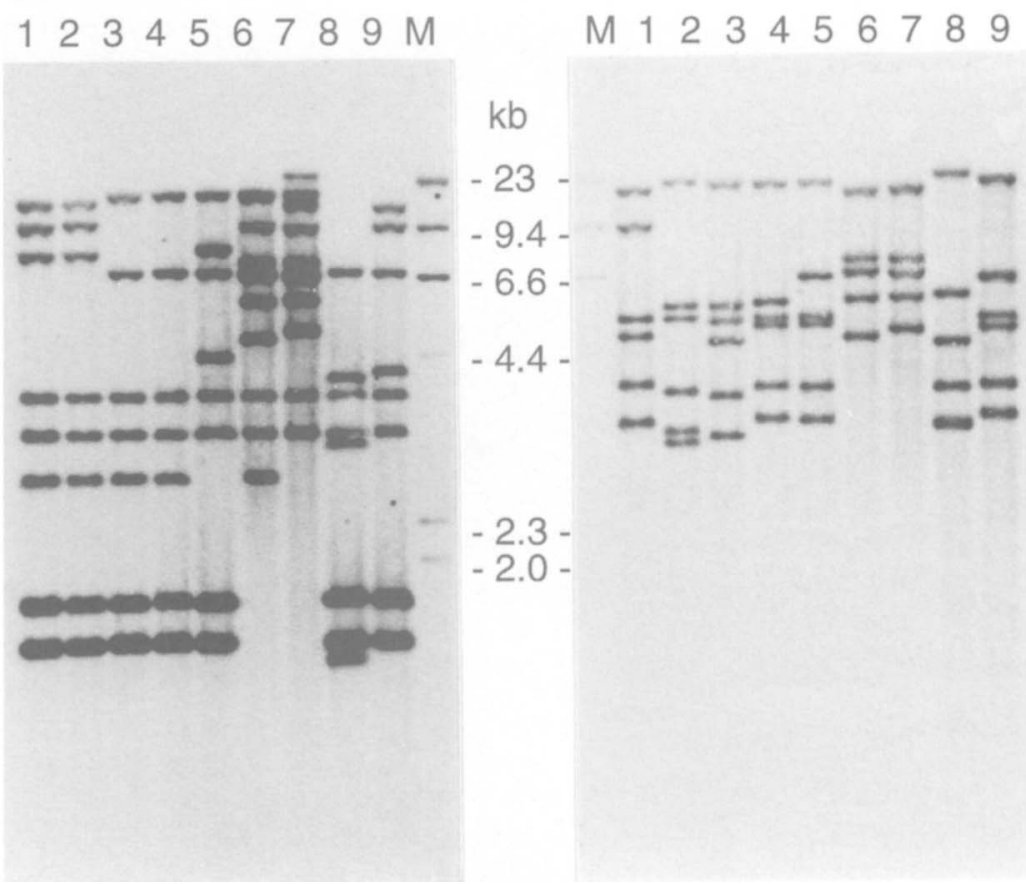

Fig. 2. a, Traditional ribotyping patterns of NCHI investigated in the present study showing Southern blots of EcoRIdigested DNA hybridised with a cDNA probe from $16 \mathrm{~S}$ and $23 \mathrm{~S}$ rRNA. Lanes 1-9 correspond to strains 1-9 (see Table 1). M, molecular size markers (digoxigenin-labelled HindIII fragments of bacteriophage $\lambda$ ). b, Ribotyping patterns of NCHI probed with separate PCR-generated probes for entire $16 \mathrm{~S}$ rDNA (left) and 23S rDNA (right). Lanes as for $\mathbf{a}$. 
Table 1. Differentiation of NCHI strains by probe-based ribotyping, PCR-ribotyping and restriction analysis of $r r n$ amplification products (column entries indicate the assigned pattern number)

\begin{tabular}{|c|c|c|c|c|c|c|c|c|c|c|c|c|c|}
\hline \multirow[b]{2}{*}{ Strain } & \multirow{2}{*}{$\begin{array}{l}\text { Original } \\
\text { number* }\end{array}$} & \multicolumn{3}{|c|}{ Ribotype $\uparrow$} & \multicolumn{4}{|c|}{$16 \mathrm{~S}$ rDNA restriction ${ }^{\ddagger}$} & \multicolumn{4}{|c|}{$23 \mathrm{~S}$ rDNA restriction ${ }^{\S}$} & \multirow{2}{*}{$\begin{array}{c}\mathrm{F} 2-\mathrm{R} 3 \text { Product } \\
\text { Hae III }\end{array}$} \\
\hline & & cDNA & $16 \mathrm{~S}$ & $23 \mathrm{~S}$ & Alu I & Taq I & Hha I & Hae III & Alu I & Taq I & Hhal & Hae III & \\
\hline 1 & 219 & 1 & I & $\mathrm{i}$ & $\mathrm{A} 2$ & $\mathrm{~T} 2$ & $\mathrm{Hl}$ & E2 & al & tl & h1 & $\mathrm{e} 1$ & Ll \\
\hline 2 & 40 & 2 & I & ii & $\mathrm{A} 2$ & $\mathrm{~T} 2$ & H1 & $\mathrm{E} 2$ & a1 & $\mathrm{t} 2$ & h2 & el & Ll \\
\hline 3 & 230 & 3 & II & iii & $\mathrm{A} 2$ & $\mathrm{~T} 2$ & H1 & E2 & $\mathrm{a} 2$ & $\mathrm{t} 3$ & h3 & e2 & L2 \\
\hline 4 & 280 & 4 & Il & iv & $\mathrm{A} 2$ & $\mathrm{~T} 2$ & $\mathrm{H} 1$ & $\mathrm{E} 2$ & a3 & $\mathrm{t} 4$ & h4 & e3 & L3 \\
\hline 5 & 307 & 5 & III & $\mathrm{v}$ & $\mathrm{A} 2$ & $\mathrm{~T} 2$ & H1 & E2 & al & t5 & h5 & e4 & L4 \\
\hline 6 & 354 & 6 & IV & vi & $\mathrm{A} 2$ & $\mathrm{~T} 2$ & $\mathrm{H} 1$ & E2 & $\mathrm{a} 4$ & 16 & h6 & e5 & L5 \\
\hline 7 & 51 & 7 & $\mathrm{~V}$ & vii & $\mathrm{A} 2$ & $\mathrm{~T} 1$ & $\mathrm{H} 1$ & E3 & a5 & $\mathrm{t} 7$ & h7 & e6 & L6 \\
\hline 8 & 139 & 8 & VI & viii & $\mathrm{A} 1$ & $\mathrm{~T} 1$ & $\mathrm{H} 1$ & E1 & $a 6$ & t7 & h8 & e7 & $\mathrm{L} 7$ \\
\hline 9 & 178 & 9 & VII & ix & $\mathrm{A} 2$ & $\mathrm{~T} 2$ & $\mathrm{H} 1$ & E3 & $a 6$ & t7 & h8 & e8 & L8 \\
\hline \multicolumn{2}{|c|}{$\begin{array}{l}\text { Total number } \\
\text { of patterns }\end{array}$} & 9 & 7 & 9 & 2 & 2 & 1 & 3 & 6 & 7 & 8 & 8 & 8 \\
\hline
\end{tabular}

${ }^{*}$ Designation in James et al. [18].

$\dagger E c o$ RI restriction patterns when hybridised with each probe indicated. These patterns are shown in Fig. $2 \mathrm{a}$ and $\mathrm{b}$.

${ }^{\ddagger}$ Pattern numbers indicate the lane position in Fig. 3 (i.e., A2 = 2nd lane of AluI digests).

${ }^{\S}$ Hha I and Hae III patterns of $23 \mathrm{~S}$ rDNA are shown in Figs. 4 and 5 , respectively.

\section{Restriction analysis of $23 S$ rDNA}

A c. $2.5-\mathrm{kb} 23 \mathrm{~S}$ rDNA product was amplified from all the study strains. EcoRI did not digest the product. Hha I produced a major fragment (an intensely staining

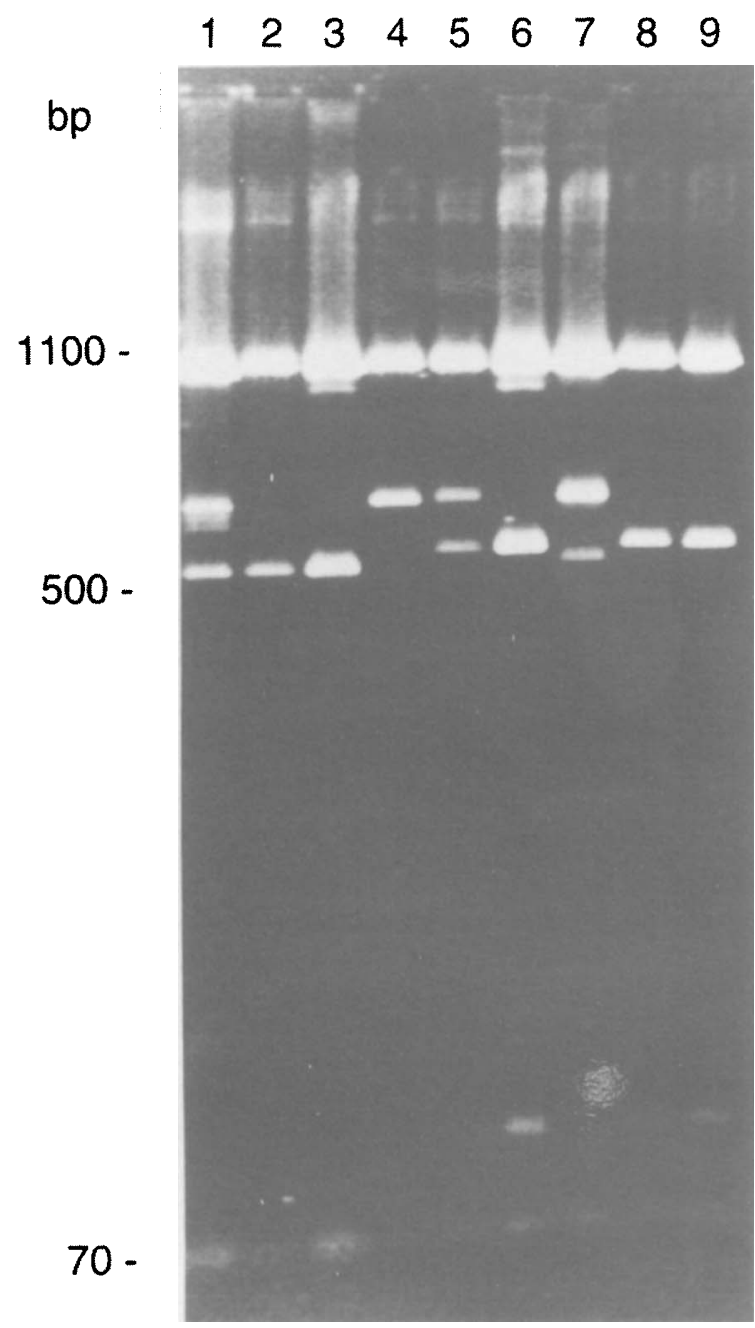

Fig. 4. Hha I restriction analysis of $23 \mathrm{~S}$ rDNA amplification products. Lane numbers correspond to strain numbers. band) of $1.0 \mathrm{~kb}$, and one to four minor fragments (less intensely staining bands) of $0.5-1 \mathrm{~kb}$, resulting in eight different patterns for the nine strains (Fig. 4). These patterns were not easy to read or compare as only two different bands with similar mobilities were detected with some strains. Hae III produced six to nine bands of 70-700 bp, giving eight patterns for the nine strains (Fig. 5). Digestion with TaqI resulted in one major fragment of $1.0 \mathrm{~kb}$ in all strains, plus seven to nine minor products, of $100-500 \mathrm{bp}$, giving seven patterns. Alu I digestion yielded a $600-\mathrm{bp}$ product and seven to nine products of $100-400 \mathrm{bp}$ from all strains, giving six patterns. Patterns were compared on the basis of the presence or absence of specific bands, regardless of intensity (i.e., reproducible faint bands were included). Some patterns differed by only a single band. The distribution of patterns obtained with the different restriction endonucleases is shown in Table 1.

$\begin{array}{llllllllllllllllllll}M & \mathrm{M} & 1 & 2 & 3 & 4 & 5 & 6 & 7 & 8 & 9 & 1 & 2 & 3 & 4 & 5 & 6 & 7 & 8 & 9\end{array}$

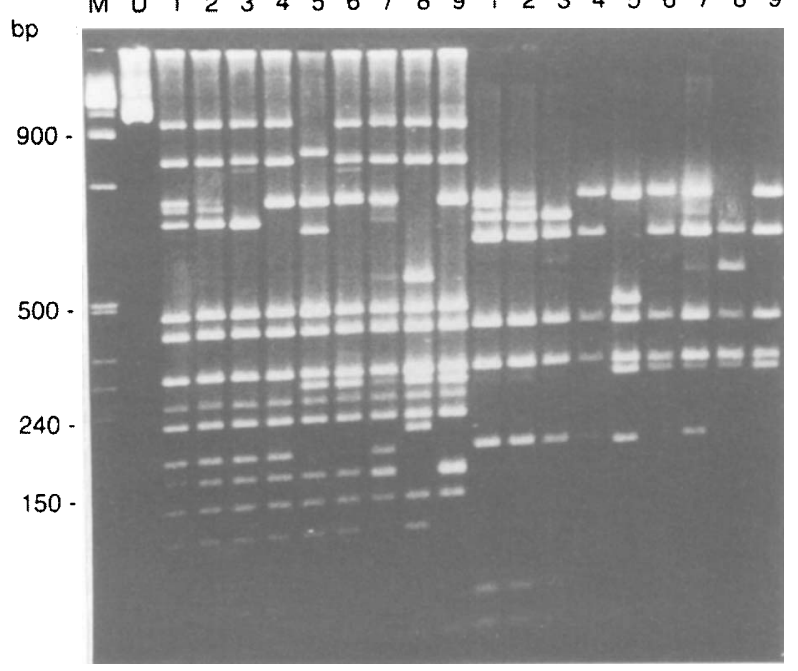

Fig. 5. Hae III restriction analysis of $\mathrm{F} 2-\mathrm{R} 3$ (left) and $23 \mathrm{~S}$ rDNA (right) amplification products. Lane numbers correspond to strain numbers. $\mathrm{M}$, molecular size markers (marker VIII, Boehringer). U, undigested 23S rDNA and $\mathrm{F} 2-\mathrm{R} 3$ products. 


\section{PCR-ribotyping and restriction analysis of the I6S-23S IGS}

PCR-ribotyping resulted in two major bands of $c$. $570 \mathrm{bp}$ and c. $820 \mathrm{bp}$, and a variable faint band in all nine strains. The faint, variable band was always at the same position in all patterns on any given gel, usually between the two major bands, but occasionally above the larger product. When amplification products from experiments in which the fainter band was in different positions were re-run on the same gel, the fainter bands were all in the same position. This phenomenon has been documented previously [10] and suggests that these bands were not fragments of double-stranded DNA. The nine strains were indistinguishable by PCRribotyping. The major products were not digested by $E c o$ RI, but an apparent increase in size of the faint band was observed. Digestion of the products with four restriction endonucleases with four-base recognition sequences resulted in indistinguishable patterns of two to four bands in all isolates. Fig. 6 shows the amplification products and the patterns obtained after digestion.

\section{Restriction of $5^{\prime}$-region of $23 S$ rDNA}

As expected, amplification with primers $\mathrm{F} 1$ and R3 gave products of $c .3 .3 \mathrm{~kb}$ and $c .3 .5 \mathrm{~kb}$ for each strain. EcoRI digestion yielded products of c. $2.7 \mathrm{~kb}$, c. $0.9 \mathrm{~kb}$ and c. $0.7 \mathrm{~kb}$ for seven strains, but did not appear to cut the amplification products from the remaining two strains. The other primer pair (F2, R3) gave two products of $c .5 \mathrm{~kb}$ for each strain, as expected. For seven strains, digestion with EcoRI resulted in products of c. $2.7 \mathrm{~kb}$, c. $1.8 \mathrm{~kb}, 1.5 \mathrm{~kb}$ and $700 \mathrm{bp}$, while two strains gave fragments of $700 \mathrm{bp}$ and two fragments of c. $4 \mathrm{~kb}$ (Fig. 7). As Hae III produced the most patterns from 16S rDNA and 23S rDNA products, the $\mathrm{F} 1-\mathrm{R} 3$ product was also digested with this enzyme. Eight patterns, comprising 11-14 bands of $0.1-c .1 .7 \mathrm{~kb}$, were detected (Fig. 5).

The distribution and number of patterns obtained after restriction analysis of the various amplification products are summarised in Table 1. The position of the EcoRI sites in the operon and the relative positions of the primers used in the present study are indicated in Fig. 1.

\section{Discussion}

The present study investigated the source of variation detected in traditional probe-based ribotyping patterns of NCHI. Previous ribotyping studies of $H$. influenzae from the UK showed that, of 12 restriction endonucleases tested, EcoRI gave the most discriminatory patterns $[19,24]$. The variation in these ribotyping patterns must, therefore, be a result of differences in $E c o$ RI sites, either within the operons or flanking them.

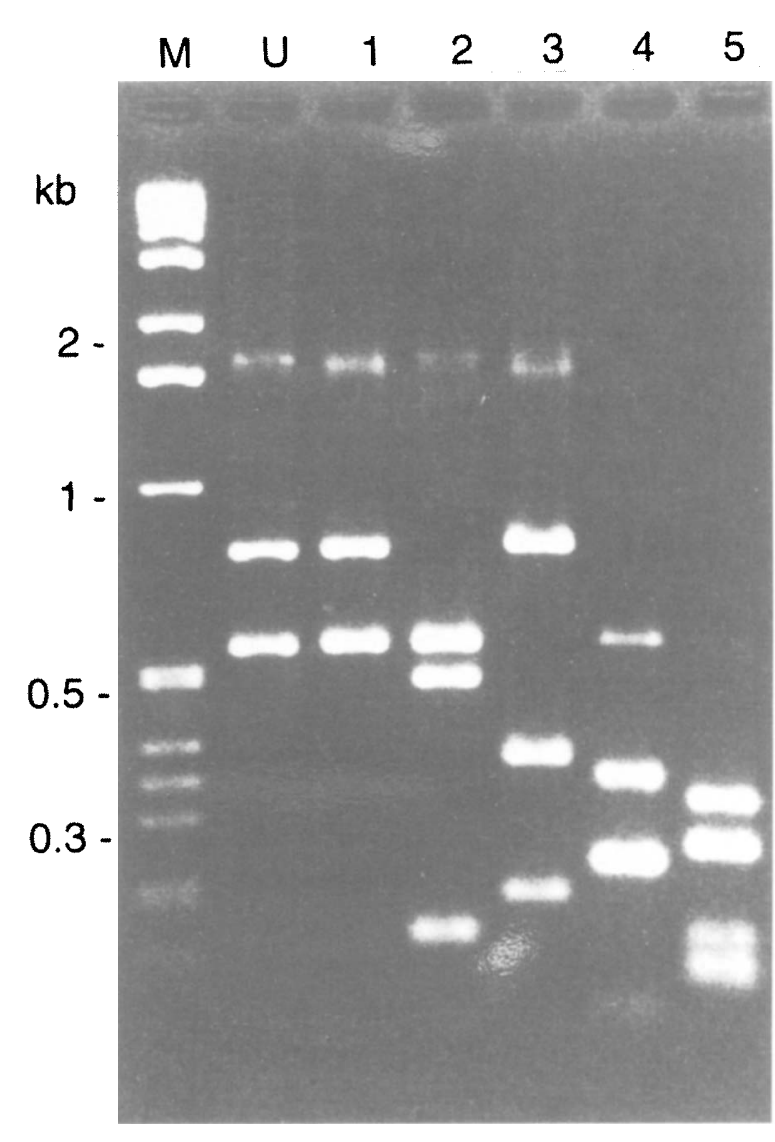

Fig. 6. Amplification and restriction analysis of $16 \mathrm{~S}-23 \mathrm{~S}$ IGS. M, molecular size markers (1-kb ladder); U, undigested product; lanes 1-5 show products digested with EcoRI, Hha I, Hae III, TaqI (partial digest showing undigested product) and $A l u \mathrm{I}$, respectively.

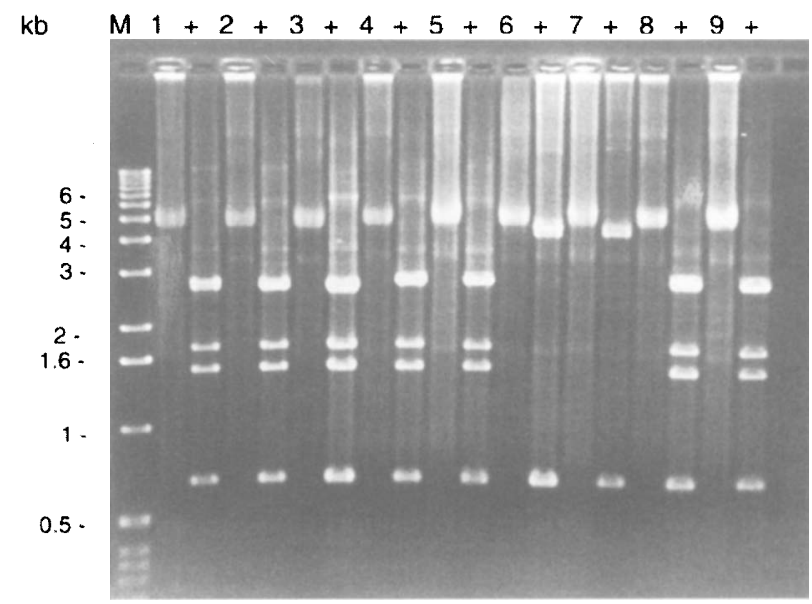

Fig. 7. Restriction analysis of F2-R3 product with EcoRI. Lane numbers 1-9 represent undigested product from strains $1-9$; + indicates EcoRI fragments obtained from the product in the preceding track. $M$, molecular size markers (1-kb ladder).

Amplification and restriction analysis of $c .5 \mathrm{~kb}$ of the rrn operon, comprising almost the entire 16S rDNA, $23 \mathrm{~S}$ rDNA and 16S-23S IGS, showed that there was one EcoRI site in 16S rDNA (conserved in all nine strains examined) and another EcoRI site at the $5^{\prime}$ - end 
of $23 \mathrm{~S}$ rDNA; this was conserved in seven of nine strains (Fig. 1). No other EcoRI sites were detected. The variation in EcoRI ribotyping patterns must, therefore, result from variation in EcoRI sites outside the $c$. 5-kb region examined. The positions of these EcoRI sites were conserved in all $r r n$ copies present within a genome, as indicated by the sizes of the $E c o$ RI restriction fragments of the various amplification products (i.e., the sum of the fragment sizes was equal to the size of the product, and no product was left undigested).

Comparison of the ribotyping patterns obtained with separate probes for 16S rDNA and 23S rDNA, together with details of the positions of the EcoRI sites within the operon, confirmed that most variation lay outside $r r n$. Ribotyping patterns obtained with a $16 \mathrm{~S}$ rDNAspecific probe showed two intense hybridisation bands at $c .1 .5 \mathrm{~kb}$ and $1.8 \mathrm{~kb}$ to be common to all strains with an EcoRI site in the $23 \mathrm{~S}$ gene (Fig. 2b, left); these represent all copies of the $3^{\prime}-16 S+$ IGS fragments (Fig. 1). Therefore, the other hybridisation bands in these strains correspond to fragments containing a common 3 '-end (the conserved EcoRI site in $16 \mathrm{~S}$ rDNA) and the 5 '-end of each copy of $16 \mathrm{~S}$ rDNA plus its associated flanking sequence. Variation in these bands must represent variation in DNA upstream from 16S rDNA. Two bands were shared by all nine strains studied, and two other bands were present in the majority of strains, indicating that there is relatively little variation in EcoRI sites upstream from the operons. This may be related to the presence of several tRNA genes upstream. Fleischmann et al. [25] demonstrated three tRNA genes upstream and two tRNA gene downstream from $r r n$ in $H$. influenzae strain $\mathrm{Rd}$. The two intense $16 \mathrm{~S}$ hybridisation bands, representing 3 '-16S + IGS, have been shown to be present in all HIB isolates examined by this laboratory to date [24] and in the vast majority of NCHI isolates [19; unpublished observations], suggesting that the two EcoRI sites are conserved in most $H$. influenzae strains. The difference in size of these hybridisation bands corresponds to the two different lengths of IGS characterised in the present study, which probably results from a difference in the number of tRNA genes present in the spacer [26]. Fleischmann et al. [25] demonstrated that the spacers are $478 \mathrm{bp}$ or $723 \mathrm{bp}$ long and contain one or two tRNA genes, respectively, in strain $\mathrm{Rd}$. For patterns obtained with the $23 \mathrm{~S}$ rDNA-specific probe, restriction fragments that hybridised must each have a common 5'-sequence-the EcoRI site at the $5^{\prime}$-end of $23 \mathrm{~S}$ rDNA (or, if this is absent, the site in 16S rDNA) - and the 3 '-end of each copy of $23 \mathrm{~S}$ rDNA plus its associated flanking sequence. Variation in these bands must indicate variation in flanking DNA downstream from the operons. Fewer hybridisation bands were shared by these patterns than by $16 \mathrm{~S}$ rDNA hybridisation patterns, indicating that the variation in EcoRI sites is $3^{\prime}$ to the region. The size of $23 \mathrm{~S}$ rDNA hybridisa- tion fragments (all $>3 \mathrm{~kb}$ ) indicates that the variable sites are all outside the operons (Fig. 2b, right).

Restriction analysis of $16 \mathrm{~S}$ rDNA, 23S rDNA and 16S-23S IGS amplification products with four other restriction endonucleases demonstrated no variation in the IGS and little variation in $16 \mathrm{~S}$ rDNA. More variation was detected in $23 \mathrm{~S}$ rDNA, although many fragments were common to several patterns, confirming the relative lack of variation within the operon. However, for strains 3 and 6 , the sum of the Hae III restriction fragments from $23 \mathrm{~S}$ rDNA exceeded the size of the original product (Fig. 5) and, for some strains, some restriction fragments were present in much less quantity than others (Figs. 4 and 5), suggesting variation between $r r n$ copies within a genome. Variation in the length of 23S rDNA and $16 \mathrm{~S}$ rDNA between strains within species has been reported previously and has been shown to result from the presence of intervening sequences [27]. The results of the present study suggest the presence of variant $r r n$ operons within the genomes of some $H$. influenzae strains.

The position of EcoRI sites within the operon, determined above, together with the results from the hybridisation studies with the separate probes, also enabled the number of $r r n$ copies within each genome to be determined. The conserved EcoRI site in $16 \mathrm{~S}$ rDNA must result in all $23 \mathrm{~S}$ genes being on separate EcoRI fragments. Therefore, the number of hybridisation bands obtained with the probe for 23S rDNA represents the minimum number of copies of the operon in the genome, so that the present study indicates the presence of five or six copies of $r r n$ in $H$. influenzae. The two strains of $H$. influenzae that have been mapped previously both possess six copies of $r r n[25,28,29]$. The five hybridisation bands detected with the $23 \mathrm{~S}$-specific probe for two strains in the present study suggest the presence of five operons. Alternatively, two separate fragments containing $r r n$ operons may be of similar size and co-migrate under the conventional agarose gel electrophoresis conditions used in the present study. However, the presence of five $r r n$ copies in strains 6 and 7, and six $r r n$ copies in the remaining strains, was confirmed by the results with the $16 \mathrm{~S}$ rDNA probe.

In addition to causing nosocomial outbreaks of respiratory infection [3], NCHI are recognised increasingly as an important cause of invasive disease [30] and are not expected to decline in response to the recent introduction of the vaccine against HIB [31]. Highly discriminatory methods of strain characterisation are therefore necessary for epidemiological investigations, and global studies require standardised, reproducible methods. The present study compared different $r r n$-based methods for their ability to discriminate NCHI strains. In traditional probe-based ribotyping of 40 isolates, the $16 \mathrm{~S}$ probe was less 
discriminatory than the classic combined probe for $16 \mathrm{~S}$ and $23 \mathrm{~S}$ rDNA. Nine strains with different traditional ribotyping patterns, including two pairs indistinguishable with the $16 \mathrm{~S}$ rDNA probe, were investigated further. The $23 \mathrm{~S}$ rDNA probe gave nine patterns, but fewer bands (which were less well distributed) than the combined probe, making pattern comparisons less sensitive but simpler. Restriction analysis of $16 \mathrm{~S}$ rDNA and $23 \mathrm{~S}$ rDNA amplification products classified the nine isolates into a maximum of three and eight patterns, respectively. Amplification of the $16 \mathrm{~S}-23 \mathrm{~S}$ IGS (PCR-ribotyping), with or without subsequent digestion, failed to distinguish any of the nine strains. The two pairs of strains indistinguishable by $16 \mathrm{~S}$ rDNA probing were also indistinguishable by $16 \mathrm{~S}$ rDNA restriction patterns. The 23S rDNA restriction fragment patterns distinguished these strains, although strains 1 and 2 were distinguishable only with TaqI and HhaI. This suggests that all 16S rDNA-based methods are poorly discriminatory for NCHI. The lack of perfect correlation between the results of the different methods is probably related to different selection pressures on sequences outside $r r n$ and those within $r r n$. Although rapid methods are desirable for the investigation of outbreaks of infection in hospitals, none of the rrndirected PCR-based methods investigated in the present study were as discriminatory for $\mathrm{NCHI}$ as traditional probe-based ribotyping. It was noticeable that the whole $16 \mathrm{~S}$ rDNA or $23 \mathrm{~S}$ rDNA PCRgenerated probes produced bands of hybridisation with an even intensity, whilst the $16 \mathrm{~S}+23 \mathrm{~S}$ cDNA probe produced bands of varying intensity. Differences in band intensity have been shown previously to be a stable and differential marker for the characterisation of HIB [24]. The PCR-generated probes consist of a whole piece of DNA $(1.5 \mathrm{~kb}$ or $2.5 \mathrm{~kb}$ in length for $16 \mathrm{~S}$ rDNA and $23 \mathrm{~S}$ rDNA, respectively) containing digoxigenin-labelled dUTP. In contrast, the $16 \mathrm{~S}+23 \mathrm{~S}$ cDNA probe is made by random priming and therefore consists of many smaller probes, also digoxigenin-labelled, but of perhaps only a few hundred bp. Following hybridisation at high stringency with the cDNA probe, the amount of rDNA in a specific chromosomal restriction fragment on the filter is directly proportional to the intensity of the hybridisation band. In contrast, the intensity of the hybridisation band with the PCR-generated probes is independent of the amount of rDNA in the fragment; when sufficient rDNA is present to form a stable hybrid, the resulting bands are of an even intensity as the probe is uniform. The cDNA probe for $16 \mathrm{~S}$ rDNA and $23 \mathrm{~S}$ rDNA detected the most heterogeneity and, therefore, should remain the standard for epidemiological investigations of NCHI.

Traditional ribotyping has been shown to be highly discriminatory for some species, but the use of different restriction endonucleases and probes for a single species makes inter-laboratory comparisons difficult. The most appropriate restriction endonuclease (i.e., detecting the most variation) for a species may be difficult to standardise because bacterial populations may differ with geographical location; thus EcoRI ribotyping was shown to be highly discriminatory for enterococci from Oxford, but not for strains from London [32, 33]. Similarly, the distribution of subtypes within HIB has been shown to vary between host populations [34] and geographical regions [35]. Nevertheless, standardisation is vital for global comparisons of bacterial populations. The present study has shown that the major source of variation detected in ribotyping patterns is in the flanking DNA sequence. The use of probes containing a small part of the operon, e.g., an oligonucleotide probe for $16 \mathrm{~S}$ rDNA [36], may be suitable if all the particular restriction sites and variations in these were outside $r r n$; however, the presence of conserved restriction sites within $r r n$, as shown in the present study, would decrease the discriminatory power of the method as all fragments would have a common end. Probes containing more of the operon inherently detect more variation, both within and outside the operon, and are therefore preferable. The use of the entire operon from one species as a universal, standard probe may be inappropriate as spacer regions vary within and between species and genera, as indicated by recent PCR-ribotyping studies $[11,13,37]$. The combined use of PCR-generated probes for $16 \mathrm{~S}$ and $23 \mathrm{~S}$ rDNA, as in the present study, gave essentially the same results as the cDNA probe, showing that either was satisfactory for ribotyping NCHI. The addition of $5 \mathrm{~S}$ rDNA sequence to this probe may increase discrimination further for some species.

The multicopy, stable and essential nature of $r r n$ makes it an ideal target for identification, but this study has shown that it is the dispersed location of $r r n$ around the genome that makes ribotyping sufficiently discriminatory for epidemiological purposes; therefore, it may not be an ideal target for PCR-based strain characterisation as sequences within the operon are generally highly conserved. ARDRA and PCR-ribotyping are probably suited more to inter-species identification than intra-species characterisation for epidemiological studies. Analysis of 16S rRNA has been used extensively for phylogenetic studies $[10,38]$ and has shown that there is little sequence variation within species. Similarly, rrn spacer regions from Staphylococcus aureus have been shown recently to have a high degree of sequence conservation [26]. PCR-ribotyping, which has been shown to discriminate between strains within other species, failed to distinguish any of the strains in the present study. Restriction analysis of individual 16S, 23S and IGS products increased discrimination, but was still less discriminatory than cDNA probe-based ribotyping for NCHI. In contrast, restriction analysis of a single 5.5$\mathrm{kb}$ amplification product from $r r n$ ('long PCR ribotyping') has shown that internal Hae III sites were 
highly polymorphic within the operon [39]. These results may be a reflection of the strains investigated. For NCHI, the highly conserved nature of rrn, as demonstrated in the present study, shows that there is insufficient variation to make this a good target for PCR-based methods of strain characterisation. As $H$. influenzae has been shown to be one of the most heterogeneous bacterial species [40], these results suggest that this target is also unlikely to be suitable for characterising strains of other species. As the source of variation detected in traditional ribotyping is the DNA flanking the operons, it may be preferable for PCR-based methods of strain characterisation to target regions other than $r r n$.

J. Z. J. thanks J. V. Hookey, Central Public Health Laboratory, London, for help with retrieval of sequence data from Genbank.

\section{References}

1. Bingen EH, Denamur E, Elion J. Use of ribotyping in epidemiological surveillance of nosocomial outbreaks. Clin Microbiol Rev 1994; 7: 311-327.

2. Saunders NA, Harrison TG, Haththotuwa A, Taylor AG. A comparison of probes for restriction fragment length polymorphism (RFLP) typing of Legionella pneumophila serogroup 1 strains. J Med Microbiol 1991; 35: 152-158.

3. Jordens JZ, Leaves NI, Anderson EC, Slack MPE, Polymerase chain reaction-based strain characterization of noncapsulate Haemophilus influenzae. J Clin Microbiol 1993; 31: 29812987.

4. Meunier J-R, Grimont PAD. Factors affecting reproducibility of random amplified polymorphic DNA fingerprinting. Res Microbiol 1993; 144: 373-379.

5. Vaneechoutte $\mathrm{M}$, de Beenhouwer $\mathrm{H}$, Claeys $\mathrm{G}$ et al. Identification of Mycobacterium species by using amplified ribosomal DNA restriction analysis. J Clin Microbiol 1993; 31: 2061-2065.

6. Vaneechoutte M, Dijkshoorn L, Tjernberg I et al. Identification of Acinetobacter genomic species by amplified ribosomal DNA restriction analysis. J Clin Microbiol 1995; 33: 11-15.

7. Jayarao BM, Doré JJE, Oliver SP. Restriction fragment length polymorphism analysis of $16 \mathrm{~S}$ ribosomal DNA of Streptococcus and Enterococcus species of bovine origin. J Clin Microbiol 1992; 30: 2235-2240

8. Milsom SE, Sprague SV, Dymock D, Weightman AJ, Wade WG. Rapid differentiation of Prevotella intermedia and $P$. nigrescens by $16 \mathrm{~S}$ rDNA PCR-RFLP. J Med Microbiol 1996; 44: 41-43.

9. Laguerre G, Rigottier-Gois L, Lemanceau P. Fluorescent Pseudomonas species categorized by using polymerase chain reaction (PCR)/restriction fragment analysis of $16 \mathrm{~S}$ rDNA. $\mathrm{Mol}$ Ecol 1994; 3: 470-487.

10. Jensen MA, Webster JA, Straus N. Rapid identification of bacteria on the basis of polymerase chain reaction-amplified ribosomal DNA spacer polymorphisms. Appl Environ Microbiol 1993; 59: 945-952.

11. Dasen SE, LiPuma JJ, Kostman JR, Stull TL. Characterization of PCR-ribotyping for Burkholderia (Pseudomonas) cepacia. $J$ Clin Microbiol 1994; 32: 2422-2424.

12. Kostman JR, Edlind TD, LiPuma JJ, Stull TL. Molecular epidemiology of Pseudomonas cepacia determined by polymerase chain reaction ribotyping. J Clin Microbiol 1992; 30: 2084-2087.

13. Cartwright CP, Stock F, Beekmann SE, Williams EC, Gill VJ. PCR amplification of rRNA intergenic spacer regions as a method for epidemiologic typing of Clostridium difficile. $J$ Clin Microbiol 1995; 33: 184-187.

14. Auriol J, Guesdon J-L, Guibourdenche M, Riou JY. Characterisation of serogroup A Neisseria meningitidis strains by rRNA gene restriction patterns and PCR: correlation with the results of serotyping, subtyping and multilocus enzyme electrophoresis. FEMS Immunol Med Microbiol 1995; 10: 219-226.
15. Kostman JR, Alden MB, Mair M, Edlind TD, LiPuma JJ, Stull TL. A universal approach to bacterial molecular epidemiology by polymerase chain reaction ribotyping. J Infect Dis 1995; 171: 204-208.

16. Matar GM, Swaminathan B, Hunter SB, Slater LN, Welch DF. Polymerase chain reaction-based restriction fragment length polymorphism analysis of a fragment of the ribosomal operon from Rochalimaea species for subtyping. J Clin Microbiol 1993; 31: 1730-1734.

17. Olsen GJ, Woese CR. Ribosomal RNA: a key to phylogeny. FASEB $J$ 1993; 7: 113-123.

18. James PA, Lewis DA, Jordens JZ, Cribb J, Dawson SJ, Murray $\mathrm{SA}$. The incidence and epidemiology of $\beta$-lactam resistance in Haemophilus influenzae. J Antimicrob Chemother 1996; 37 : 737-746.

19. Bruce KD, Jordens JZ. Characterization of noncapsulate Haemophilus influenzae by whole-cell polypeptide profiles, restriction endonuclease analysis, and rRNA gene restriction patterns. J Clin Microbiol 1991; 29: 291-296.

20. Anderson P, Johnston RB, Smith DH. Human serum activities against Haemophilus influenzae type b. J Clin Invest 1972; 51: $31-38$.

21. Dewhirst FE, Paster BJ, Olsen I, Fraser GJ. Phylogeny of 54 representative strains of species in the family Pasteurellaceae as determined by comparison of $16 \mathrm{~S}$ rRNA sequences. $J$ Bacteriol 1992; 174: 2002-2013.

22. Greisen K, Loeffelholz M, Purohit A, Leong D, PCR primers and probes for the 16S rRNA gene of most species of pathogenic bacteria, including bacteria found in cerebrospinal fluid. J Clin Microbiol 1994; 32: 335-351.

23. Van Camp G, Chapelle S, De Wachter R. Amplification and sequencing of variable regions in bacterial 23S ribosomal RNA genes with conserved primer sequences. Curr Microbiol 1993; 27: $147-151$.

24. Leaves NI, Jordens JZ. Development of a ribotyping scheme for Haemophilus influenzae type b. Eur J Clin Microbiol Infect Dis 1994; 13: 1038-1045.

25. Fleischmann RD, Adams MD, White $\mathrm{O}$ et al. Whole-genome random sequencing and assembly of Haemophilus influenzae Rd. Science 1995; 269: 496-512.

26. Gurtler V, Barrie HD. Typing of Staphylococcus aureus strains by PCR-amplification of variable-length 16S-23S rDNA spacer regions: characterization of spacer sequences. Microbiology 1995; 141: 1255-1265.

27. Linton D, Clewley JP, Burnens A, Owen RJ, Stanley J. An intervening sequence (IVS) in the 16S rRNA gene of the eubacterium Helicobacter canis. Nucleic Acids Res 1994; 22: $1954-1958$

28. Barcak GJ, Chandler GS, Redfield RJ, Tomb J-F. Genetic systems in Haemophilus influenzae. Methods Enzymol 1991; 204: 321-342.

29. Butler PD, Moxon ER. A physical map of the genome of Haemophilus influenzae type b. J Gen Microbiol 1990; 136: 2333-2342.

30. Murphy TF. Invasive $H$. influenzae infections in adults? Another clinical pearl down the drain! Infect Dis Clin Pract 1994; 3: 41-43.

31. Slack MPE. Invasive Haemophilus influenzae disease: the impact of Hib immunisation. J Med Microbiol 1995; 42: $75-77$.

32. Hall LMC, Duke B, Guiney M, Williams R. Typing of Enterococcus species by DNA restriction fragment analysis. J Clin Microbiol 1992; 30: 915-919.

33. Jordens JZ, Bates J, Griffiths DT. Faecal carriage and nosocomial spread of vancomycin-resistant Enterococcus faecium. J Antimicrob Chemother 1994; 34: 515-528.

34. Saravani GA, Martin DR, Arriesgado MT, Haemophilus influenzae in New Zealand: subtyping of isolates from invasive disease using outer-membrane protein profiling $N Z$ Med $J$ 1992; 105: 218-220.

35. van Alphen L, Geelan L, Jónsdóttir K, Takala AK, Käyhty H, Zanen HC. Distinct geographic distribution of subtypes of Haemophilus influenzae type b in Western Europe. J Infect Dis 1987; 156: 216-218.

36. Crowe M, Towner KJ, Humphreys $\mathrm{H}$. Clinical and epidemiological features of an outbreak of acinetobacter infection in an intensive therapy unit. $J$ Med Microbiol 1995; 43: 55-62.

37. Whiley RA, Duke B, Hardie JM, Hall LMC. Heterogeneity among 16S-23S rRNA intergenic spacers within the 
“Streptococcus milleri group". Microbiology 1995; 141: 1461 1467.

38. Weisburg WG, Barns SM, Pelletier DA, Lane DJ. 16S ribosomal DN amplification for phylogenetic study. $J$ Bacteriol 1991; 173: 697-703.
39. Smith-Vaughan HC, Sriprakash KS, Mathews JD, Kemp DJ. Long PCR-ribotyping of nontypeable Haemophilus influenzae. $J$ Clin Microbiol 1995; 33: 1192-1195.

40. Pennington TH. Haemophilus species and clones. Rev Med Microbiol 1993; 4: 50-58. 